\title{
Bruk av legenes tid og ressurser
}

\author{
Jeg har 18 års fartidstid som blodtrykkspasient, og i alle disse årene har jeg følt meg plassert i en kunstig \\ og unødvendig pasientrolle. Går det an å endre på?
}

Jeg er en av 800000 nordmenn som går på blodtrykksmedisin. Jeg føler meg likevel frisk og har ikke andre risikofaktorer ved siden av. Sist jeg var hos legen, sa jeg: «Nå er jeg hos legen, og jeg føler meg så frisk og opplagt.» Vi lo begge to. Blodtrykket ble målt og var helt fint. Er det slik at friske mennesker ofte blir sykeliggjort og unødvendig plassert i pasientrollen?

Alle vet vi at det er svært viktig å kontrollere blodtrykket for å forebygge farlige sykdommer. Og alle vet vi at helsebudsjettet er i ferd med å sprekke. Likevel er venterommene på legesentrene fulle av friske mennesker som kunne gjort mye av legens jobb selv.

Kan du og jeg ta mer ansvar for vår egen helse? Bør vi lære oss til å tenke at vi i større grad må være vår egen lege og ta mer ansvar for blodtrykksbehandlingen?

Rett på sak: Hva om alle blodtrykkspasienter fikk sitt eget blodtrykksapparat på blå resept? En sykepleier tilknyttet det lokale legesenteret kunne bistå med opplæring i riktig bruk av apparatet og hvordan vi skulle notere blodtrykksverdiene. Et eksempel: «Kari» har fått opplæring i å måle blodtrykket selv hjemme. Hun noterer dato, klokkeslett og verdier. En gang hvert halvår eller årlig sender hun inn sine data elektronisk (med pinkode) til sitt lokale legesenter. En gang i uken leser legen av selvinnsendte data. Hvis «Kari» må endre medisindosene, får hun innkalling til ny legetime. Er alt fint, hører hun ingenting og sender så inn nye data om et halvt eller ett år.

Mitt eksempel her tror jeg kan overføres til flere andre sykdomsgrupper. Jeg tror også at det er viktig at brukeren aktivt medvirker i sin egen behandling. Mitt motto er: «Min helse er mitt ansvar, og min lege er min rådgiver.»

At brukerne («pasientene») i større grad får innflytelse over sin behandling, kan frigjøre legenes tid, slik at disse kan bruke mer tid på de som virkelig er syke. Jeg

\section{«Min helse er mitt ansvar, og min lege er min rådgiver.»}

tenker nå på folk som sliter med rus, og som ikke får nødvendlig legehjelp. Det vil også bli bedre plass på venterommene på legekontorene og ikke minst føre til en samfunnsøkonomisk gevinst.

\author{
Gunn Pound \\ pound70@hotmail.com \\ Ole Brummsvei 36 \\ 0979 Oslo
}

Oppgitte interessekonflikter: Ingen

Manuskriptet ble mottatt 22.6. 2010 og godkjent 27.7. 2010. Medisinsk redaktør Jon Amund Kyte. 